\title{
Evaluation of Improved Common Bean (Phaseolus vulgaris L.) Varieties for Yield and Yield Components at West Hararghe, Eastern Ethiopia
}

\author{
Temesgen Begna*, Zewdu Asrat \\ Ethiopian Institute of Agricultural Research, Chiro National Sorghum Research and Training Center, P.O.Box \\ 190, Chiro, Ethiopia
}

*Corresponding Authors: Temesgen Begna, Ethiopian Institute of Agricultural Research, Chiro National Sorghum Research and Training Center, P.O.Box 190, Chiro, Ethiopia

\begin{abstract}
Common bean is playing a crucial role across the world mainly in the warm and lowland areas of the country including Ethiopia. Understanding the level of drought tolerance of the varieties available in each country is of paramount importance for breeding common bean for drought adaptation. However, the production of common bean is mainly limited due to lack of high yielding potential varieties and frequent and recurrent drought. Hence, the study was aimed to evaluate and identify the superior performance and genetic potential of improved common bean varieties for yield and yield related traits against drought. A total of 10 recently released improved common bean varieties were evaluated using a randomized complete block design (RCBD) with three replications at Mieso during the main cropping season of 2018 and 2019. The information generated on the drought tolerance of the available varieties should help in the design of a breeding strategy that incorporates adaptation traits with commercial characteristics preferred by common bean farmers for varieties to be grown in diverse environments. The combined analyses of variance revealed the presence of tremendous genetic variation among improved common bean varieties for all the studied traits except plant height and stand count at harvest, which implies the availability of substantial genetic variation among varieties. Overall, SER-125, SER-19 and Nasir common bean varieties had better performance compared to the other varieties for yield and the yield related traits. The maximum grain yield was obtained from SER-125 (2620 kgha-1) followed SER-19 (2612 kgha-1) and Nasir (2583.33 kgha-1) common bean varieties and identified as the superior improved common bean varieties. Eventually, the effect of varieties on grain yield was significant and the best performing varieties of common bean would be recommended for the specific community and its vicinity even though further study should be carried out including a number of recently released varieties for improved common bean production in the target area and also to put the recommendation on strong basis. Therefore, based on the results of this adaptation experiment, SER-125, SER-19 and Nasir were recommended for production and adoption at Mieso and other similar environments.
\end{abstract}

Keywords: Phaseolus vulgaris; Yield; Yield components; Performance; Drought stress; Yield stability

\section{INTRODUCTION}

Common bean (Phaseolus vulgaris L. $2 \mathrm{n}=2 \mathrm{x}=22$ ) is one of the principal food legume in the world and is the most important source of dietary protein in Africa (Mercati et al., 2013). Common bean is an annual crop which belongs to the family Fabaceae. It grows best in warm climate at temperature of $18^{\circ} \mathrm{C}$ to $24^{\circ} \mathrm{C}$ (Assefa, T et al., 2015). Common bean is the most widely distributed Phaseolus species as it is grown across all the continents with a broad range of adaptation to various environmental conditions (Porch et al., 2013). Population_genetic analyses revealed that wild common bean consists of two geographically isolated and genetically differentiated gene pools, Mesoamerican and Andean, which diverged about 100,000 years ago (Mamidi et al., 2013). The cultivated common bean was domesticated from the two gene pools independently about 8000 years ago and then underwent local adaptation that has led to distinct phenotypic characteristics among different cultivars (Bitocchi et al., 2013).

There are many pulse species are grown in Ethiopia. Of these, Faba bean, field pea, chickpea, lentil, grass pea, fenu greek and lupine are categorized as highland pulses and grown in the cooler highlands. On the contrary, common bean, soya bean, cowpea, pigeon pea and mung beans are principally grown in the warmer and low land parts of the country. Among the individual varieties, faba beans (broadly known as horse beans) accounts for the maximum fraction of production, at $36 \%$, followed by common 
beans (17\%) and chickpeas (16\%). Other pulses (lentils, peas, lupines and mung beans) account for the remaining 32\% (Yirga, C et al., 2019). The global production of common bean is nearly 12 million tons per annum. The East and Southern Africa regions produces about 2.5 million tons per annum (Petry, N et al., 2015). Approximately 40 per cent of Africa's production is marketed for about 450 million US dollars (Katungi, E et al., 2009), and small holder farmers account for the bulk of the cultivated crop. Common bean contributes to the national economy as both a food and an export commodity, in both cases serving as a source of income and employment to a large supply chain (Tumsa, K et al., 2014). The crop provides vital nutrients as a food including vitamins, proteins, and minerals and the stems are also used as fodder for livestock, especially in the dry spell following the main cropping season (Wondatir, Z and Mekasha, Y, 2014).

Common bean is a major grain legume which is consumed worldwide for its edible seeds and pods. It is the third most important source of calories after maize and cassava, serving millions of low-income households (Alemu H, 2017). Common bean is one of the most important legume crops, providing as much as $15 \%$ of total daily calories and $36 \%$ of total daily protein in parts of Africa and the America (Schmutz et al., 2014). According to Miklas et al. (2006), this crop has a high nutritional value with important protein contents ( 22\%), minerals (calcium, copper, iron, magnesium, manganese, zinc) and vitamins necessary to warrant the food security of people in the developing countries. Common bean is a traditional crop of the neo-tropics, where it was domesticated several thousand years ago (Teran, $\mathrm{H}$. and Singh, S.P., 2002). The East African highlands are a region of important common bean production and high varietal diversity for the crop (Shabib, J.M et al., 2013). Common bean is a legume commonly grown in sub-Saharan Africa for food, cash, animals' food, and as soil improver (McConnell M et al., 2013). Beans are often considered as the "poor man's meat" and consumed as seeds (mature or immature) as well as a vegetable (both leaves and pods) (Høgh-Jensen $\mathrm{H}$ et al., 2013). Common bean is one of the most important legumes and is high in protein, low in fat, and rich in vitamins and dietary fiber (Beebe et al., 2013). The regular consumption of common bean can reduce coronary heart disease, type II diabetes, and cancer (Krupa, 2008).

Common bean is very favored by Ethiopian farmers because of its fast maturing uniqueness that enables households to get cash returns essential to pay for food and other household needs when other crops have not yet matured (Legesse et al., 2013). The major producing regions are Oromia (mainly East Shewa, East and West Hararghe, West Arsi, and Arsi zones) and SNNPR (Gereziher et al., 2017). According to CSA, (2019), common bean takes $12.73 \%$ of the total area coverage $(1,620,497.30$ hectares) and 9.54\% (about 30,113,480.57 quintals) of the produced grain in Ethiopia. Ethiopia had got $85 \%$ of export estimated earnings from pulses, exceeding that of other pulses such as lentils, faba bean and chickpea (Merga, J.T, 2020). According to Amsalu, B et al, (2018), Ethiopia exported $14 \%$ (340,000 metric tons) of pulse production and generated \$ 255 million US dollars. Common bean can be produced either as sole crop or intercrop with cereals like maize and sorghum. This helps not only securing yield but also has the advantages of restoring soil fertility. Even though, the country has huge potential and the crop has tremendous advantages, the production and productivity has been challenging by low adoption of improved technologies, drought, and lack of improved varieties, poor cultural practices, disease, and environmental degradation (Merga, J.T, 2020).

The crop is cultivated in several agro-ecological zones and farming systems and mainly grown by smallscale farmers for household consumption, marketing and soil fertility improvement purposes (Asfaw $e t$ al., 2012). Ethiopian farmers have a higher preference to grow common beans, compared to other legumes, because they mature early, which helps them to obtain a cash income to buy food and other household needs. It also serves as an emergency crop in times of crop failure (Legesse et al., 2013). The common bean was introduced to Ethiopia in the sixteenth century and farmers have been able to adapt, develop and maintain a large genetic diversity to suit their needs. The conventional plant breeding scheme uses a narrow range of selection criteria that addresses issues related to yield, uniformity and stability. Traditional farmers, however, employ more diverse and complex selection criteria, revolving around stable crop performance over seasons and they grow a range of genotypes that meet their needs in very complex and heterogeneous environments (Ceccarelli and Grando, 2007). Breeding for drought-tolerant crops is challenging and time-consuming, owing to the need for simultaneously considering multiple abiotic and biotic factors modulating the level of drought-tolerance. Previous attempts made to evaluate genotypes for drought tolerance indicated high levels of drought tolerance in 
Evaluation of Improved Common Bean (Phaseolus vulgaris L.) Varieties for Yield and Yield Components at West Hararghe, Eastern Ethiopia

Durango landraces and some Mesoamerican common bean cultivars (Beebe et al ., 2013). Genotypic evaluation studies in Ethiopia identified drought tolerant genotypes and selection traits for improving drought adaptation in common bean (Asfaw, A and Blair, M.W, 2014).

In Ethiopia, the National Common Bean Research Program plays an important role in meeting the increasing demand for the crop by releasing improved common bean varieties. However, the common bean productivity is limited in Ethiopia and the average national yield of common bean in Ethiopia is estimated at $1300 \mathrm{~kg} \mathrm{ha}^{-1}$ on smallholder farms and $1700 \mathrm{~kg} \mathrm{ha}^{-1}$ on commercial farms (Livestock, C.S.A., 2017) in contrast to a production potential of 3000 to $4000 \mathrm{~kg} \mathrm{ha}^{-1}$ in research fields (Yirga, C et al., 2019). Therefore, there is a large gap among the actual and potential yield of a crop; and hence this calls for research interventions. Constraints that cause common bean yields include lack of suitable varieties for farmer's needs, a biotic stresses (drought, low soil fertility) and biotic stresses like pests, diseases, poor agronomic practice and limited research work. Hence, more researches are required across different agro ecology zones to boost productivity. Therefore, there is a need to develop high yielding and stress-tolerant cultivars to improve productivity.

The successful development and deployment of improved cultivars depend upon available genetic diversity and appropriate breeding strategies. The lack of the improved varieties of common bean is the major problem that plays a great role for the lower yield of the common bean (Mitiku, M and Mesera, $\mathrm{T}, 2017)$. Therefore, there is need to introduce the improved common bean varieties to the target area is paramount important to come up with improved productivity and production of common bean in the study area. Therefore, the study was conducted with the objectives to evaluate and recommend high yielding and early maturing common bean varieties in the moisture stressed areas of west Hararghe and other similar environments.

\section{MATERIALS AND METHODS}

\subsection{Description of the Experimental Location}

The field experiment 1was conducted under rain-fed conditions at Mieso Agricultural Sub- Research station during the 2018 and 2019 main cropping seasons. Mieso is located 302 kilometers away in the eastern from Addis Ababa, the capital city of Ethiopia in Oromia regional state. Its elevation is 1470 metres above sea level and is located at $8^{\circ} 30^{\prime} \mathrm{N}$ latitude and $39^{\circ} 21^{\prime} \mathrm{E}$ longitudes and with having an average maximum and minimum temperatures of $14.0^{\circ} \mathrm{C}$ and $30.01^{\circ} \mathrm{C}$ and with an average annual rainfall $763 \mathrm{~mm}$. The dominant soil type is Vertisols with pH 5.4 (Lemma, 2008).

\subsection{Plant Materials}

A total of 10 recently released improved common bean varieties were evaluated for yield and yield related characters. The improved lowland common bean varieties were released for lowland agroecologies by the national lowland pulse improvement program in different times. These materials were evaluated and released for the pros of well adaptive and stability of yield, earliness in terms of maturity, resistance to diseases, seed size and color, biomass and other quality characteristics.

Table1. Description of the experimental materials

\begin{tabular}{|l|l|l|l|l|}
\hline S.No & Variety & Agro-ecology & Status & Source \\
\hline 1 & SER-125 & Lowland & Released Variety & Melkasa ARC \\
\hline 2 & SER-119 & Lowland & Released Variety & Melkasa ARC \\
\hline 3 & Nasir & Lowland & Released Variety & Melkasa ARC \\
\hline 4 & KAT B-9 & Lowland & Released Variety & Melkasa ARC \\
\hline 5 & BZ -2 & Lowland & Released Variety & Melkasa ARC \\
\hline 6 & Awash Melka & Lowland & Released Variety & Melkasa ARC \\
\hline 7 & KAT B-1 & Lowland & Released Variety & Melkasa ARC \\
\hline 8 & Awash -2 & Lowland & Released Variety & Melkasa ARC \\
\hline 9 & Damee & Lowland & Released Variety & Melkasa ARC \\
\hline 10 & Awash -1 & Lowland & Released Variety & Melkasa ARC \\
\hline
\end{tabular}

\subsection{Experimental Design and Trial Management}

The experiment was arranged in a completely randomized block design with two replications during 2019 main cropping seasons to evaluate the varieties. The plot size was $4 \times 2.4 \mathrm{~m}\left(9.6 \mathrm{~m}^{2}\right)$ having 4 
rows with harvestable plot size of $1.6 \times 4 \mathrm{~m}\left(6.4 \mathrm{~m}^{2}\right)$ and a spacing of $0.40 \mathrm{~m}$ between rows and $0.10 \mathrm{~m}$ between plants was maintained. The spacing between replication, blocks and plots within each block was $1.50,1$ and $0.50 \mathrm{~m}$, respectively. All the standard agronomic packages and fertilizer rates of 100 $\mathrm{kgha}^{-1}$ DAP was applied at the time of planting whereas $100 \mathrm{kgha}^{-1}$ Urea fertilizer was set aside homogeneous for all treatments and urea was applied in split three times. Weeds were controlled periodically by hand weeding and other management practices like pest or disease-control was done as required.

\subsection{Data Collection}

Physiological traits of genotypes were assessed by measurement of multiple plant attributes using nondestructive sampling at different growth stages of the crop. The traits measured were: Days to flowering was recorded as the number of days form emergence to when 50\% of the plants had flowered in a plot, days to maturity based on number of days from sowing to physiological maturity of at least $90 \%$ of the plants in a plot, ground cover was counted on a plot before harvesting the pods, stand count at harvest was counted on a plot before harvesting the pods, plant height was also measured at mid pod filling stage on five plants per plot using meter stick grain yield was recorded from the four central rows of each plot.

\subsection{Statistical Analysis}

A general linear model (GLM) was used for data analysis and LSD at $P \leq 0.05$ was used for mean separation. The data were analyzed using PROC ANOVA in SAS software version 9.4 (SAS, 2018) and means were separated using Fisher's Least Significant Difference (LSD) test at 5\% level of probability as stated in Gomez and Gomez (1984).

\section{RESUlT AND DISCUSSION}

\subsection{Analysis of Variance for Yield and Yield Related Traits}

The analyses of variance (ANOVA) for all quantitative traits showed the presence of very and highly significant difference at different probability level among the common bean varieties for yield and yield related characteristics (Table-2). The combined analysis of variance exhibited very highly significant difference at $0.1 \%$ probability level in common bean varieties for grain yield $(\mathrm{kg})$ and ground cover and highly significant difference observed for (days to 50\% flowering and Days to $90 \%$ maturity at $1 \%$ probability level. This indicated the presence of considerable variation in the genetic materials for these traits and there is a possibility to improve the investigated common bean varieties with simple selection. Plant breeding is primarily depending on presence of substantial genetic variation to address the maximum genetic yield potential of the crops and simple selection can be effective to make further improvement when the genetic variation is available among the studied varieties. Presence of significant difference among common bean varieties for the studied traits ensured the presence of substantial genetic variation to be improved through selection. Hence, the obtained results encourage the presence of substantial genetic variation among varieties for the studied traits for further selection. With regards to the present experiment, the existence of genotypic variation in grain yield and yield components has been played a crucial role for common bean improvement.

Table2. Combined analysis of variance of cowpea varieties for yield and yield related traits

\begin{tabular}{|l|l|l|l|l|l|l|}
\hline Source of Variation & DTF & DTM & GC & SH & PHT & GY \\
\hline Replication & 5.033 & $21.43^{*}$ & 0.900 & $415.97^{\mathrm{ns}}$ & $32.5^{\mathrm{ns}}$ & 67290 \\
\hline Genotypes & $30.889^{* *}$ & $21.86^{* *}$ & $3.41^{* * *}$ & $746.23^{\mathrm{ns}}$ & $42.96^{\mathrm{ns}}$ & $143460^{* * *}$ \\
\hline Error & 8.2556 & 5.8778 & 0.5667 & 1017.3 & 51.01 & 413352 \\
\hline
\end{tabular}

***Very highly significant at $0.1 \%$ probability level, **highly significant at $1 \%$ probability level, *highly significant at 5\% probability, $n s=$ non-significant at 5\% probability level where, DTF=days to $50 \%$ flowering, $D T M=$ days $90 \%$ to physiological maturity, GC = ground cover, SH=stand count at harvest, $P H T=$ plant height, $G Y=$ grain yield.

\subsection{Mean Performance of cowpea Genotypes for Yield and Yield Related Traits}

The superior common bean varieties were identified based on the mean performance for different characteristics as indicated in (Table-3). The combined means result indicated that the SER-125 (2620 $\left.\mathrm{kgha}^{-1}\right)$, SER-19 $\left(2612 \mathrm{kgha}^{-1}\right)$ and Nasir $\left(2583.33 \mathrm{kgha}^{-1}\right)$ common bean varieties had the highest yield 
Evaluation of Improved Common Bean (Phaseolus vulgaris L.) Varieties for Yield and Yield Components at West Hararghe, Eastern Ethiopia

respectively. This showed the improved lowland common bean varieties had better adaptation and yield advantages at moisture stressed areas. The higher mean performance of varieties for yield under drought stress conditions suggests that common bean responds to drought stress by increasing root growth. BZ2 variety flowered (43 days) and matured (59 days) and KAT- 9 variety flowered (43 days) and matured (59 days) earlier. Significant reduction in days to flowering and days to physiological maturity as a result of drought stress was observed in the present study. Days to flowering and maturity are among the most important characteristics that need to be considered in selecting varieties when and where the shortage of rainfall is limiting factor for further improvement of yield and yield related traits. However, early maturing varieties have been shown low yield whereas the late mature varieties have shown high yield. Hence, the yield performance the varieties were not directly correlated to improve though simple selection and suggested to search for another breeding procedures to improve the yield and maturity of varieties for drought tolerance.

The earliness trait (days to flowering and days to physiological maturity) enables them to flower and mature early, therefore escaping from moisture stress, the most important drought factors that results in reduced yield. Nowadays, the development of the superior varieties in terms of yield and other many different traits very critical to address the required challenges of human population growth and climate change. Overcoming these difficult challenges will be harder in the absence of plant genetic improvement to increase agricultural productivity through addressing the problem of yield reduction and its links with pest management and climate change. Based on the mean performance, the superior common bean varieties were identified for different traits as indicated in (Table-3). Interestingly, the maximum grain yield was obtained from SER-125 (2620 kgha-1) followed by SER-19 (2612 $\left.\mathrm{kgha}^{-1}\right)$ and Nasir $\left(2583.33 \mathrm{kgha}^{-1}\right)$ common bean varieties.

Table3. Mean values of different Common bean varieties for grain yield and other agronomic characters

\begin{tabular}{|l|l|l|l|l|l|l|}
\hline Varieties & DTF & DTM & GC & SH & PHT & GY \\
\hline SER-125 & $48.00 \mathrm{ab}$ & $62.00 \mathrm{bc}$ & $2.67 \mathrm{~cd}$ & $130.33 \mathrm{a}$ & $34.35 \mathrm{a}$ & $2620.00 \mathrm{a}$ \\
\hline SER-19 & $49.67 \mathrm{ab}$ & $63.67 \mathrm{abc}$ & $2.33 \mathrm{c}$ & $128.33 \mathrm{a}$ & $33.33 \mathrm{a}$ & $2612.00 \mathrm{a}$ \\
\hline Nasir & $52.67 \mathrm{a}$ & $69.33 \mathrm{a}$ & $2.00 \mathrm{~b}$ & $127.67 \mathrm{a}$ & $32.33 \mathrm{a}$ & $2583.33 \mathrm{a}$ \\
\hline KAT-9 & $43.00 \mathrm{c}$ & $59.67 \mathrm{c}$ & $4.33 \mathrm{de}$ & $104.33 \mathrm{a}$ & $30.33 \mathrm{a}$ & $2095.00 \mathrm{ab}$ \\
\hline BZ-2 & $42.67 \mathrm{c}$ & $59.67 \mathrm{c}$ & $3.00 \mathrm{~cd}$ & $119.63 \mathrm{a}$ & $29.96 \mathrm{a}$ & $1998.33 \mathrm{bc}$ \\
\hline Awash Melka & $48.33 \mathrm{ab}$ & $66.00 \mathrm{ab}$ & $2.67 \mathrm{~cd}$ & $130.33 \mathrm{a}$ & $29.67 \mathrm{a}$ & $1987.33 \mathrm{bc}$ \\
\hline KAT-1 & $46.00 \mathrm{bc}$ & $59.67 \mathrm{c}$ & $5.00 \mathrm{e}$ & $101.00 \mathrm{a}$ & $29.33 \mathrm{a}$ & $1537.00 \mathrm{~cd}$ \\
\hline Awash-2 & $49.67 \mathrm{ab}$ & $63.27 \mathrm{abc}$ & $2.00 \mathrm{~b}$ & $138.67 \mathrm{a}$ & $28.36 \mathrm{a}$ & $1525.00 \mathrm{~cd}$ \\
\hline Damee & $46.33 \mathrm{bc}$ & $64.67 \mathrm{ab}$ & $1.67 \mathrm{a}$ & $96.33 \mathrm{a}$ & $26.32 \mathrm{a}$ & $1213.33 \mathrm{~d}$ \\
\hline Awash-1 & $50.67 \mathrm{a}$ & $64.00 \mathrm{ab}$ & $3.33 \mathrm{bcd}$ & $99.00 \mathrm{a}$ & $25.33 \mathrm{a}$ & $1031.33 \mathrm{~d}$ \\
\hline CV \% & 6.03 & 3.84 & 25.96 & 27.13 & 29.23 & 16.72 \\
\hline LSD 0.05 & 4.93 & 4.16 & 1.29 & 54.71 & 10.55 & 550.87 \\
\hline
\end{tabular}

Note: Means in a column with the same letter ( $s$ ) are not significantly different by LSD's test $(P=0.05), D T F=d a y s$ to 50\% flowering, DTM=days to physiological maturity, GC=ground cover, SH=stand count at harvest, $P H T=$ plant height, $G Y=$ grain yield, $L S D=$ Least significance difference, $C V(\%)=$ Coefficient of variation in percent.

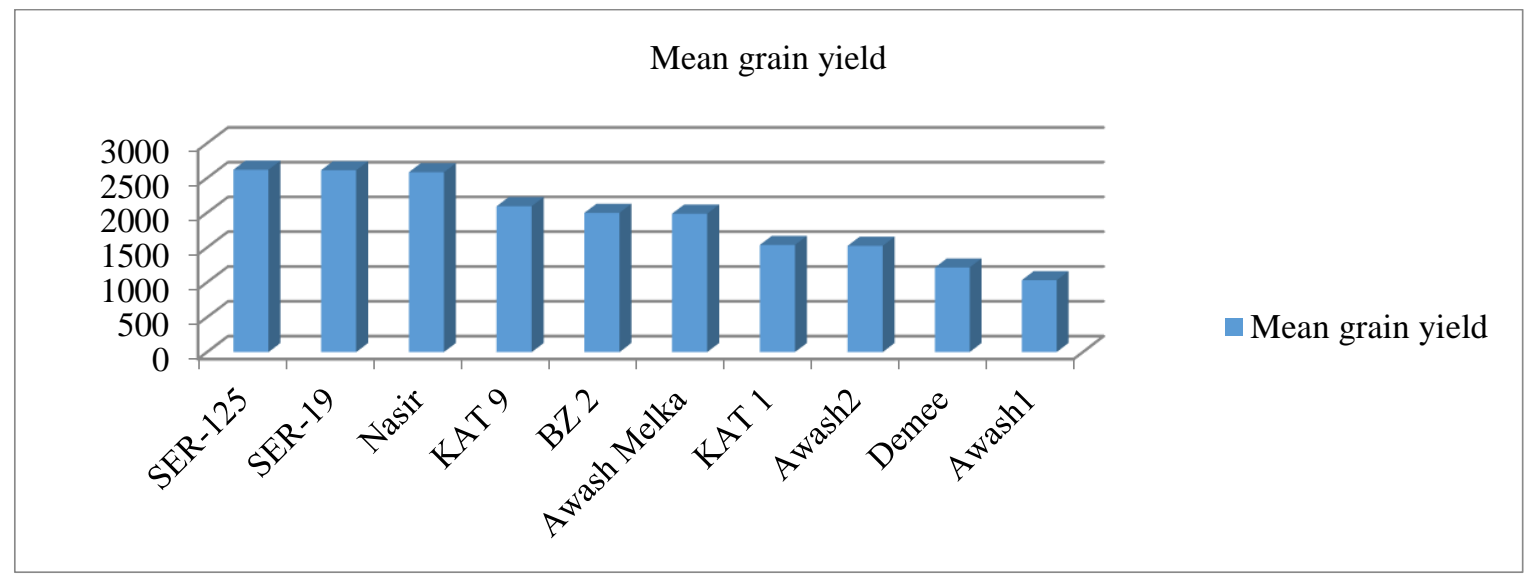

Figure1. The mean yield performance of common bean varieties in study area 


\section{CONCLuSion}

Common bean is one of Africa's most essential pulses. The adaptation of common bean varieties to drought-stress conditions is very crucial for drought prone areas particularly lowland parts of Ethiopia. Drought stress linked with climate change is one of the major constraints faced by common bean farmers in Africa and elsewhere. Mitigating this constraint requires the selection of resilient varieties that withstand drought threats to common bean production. The crop provides vital nutrients as a food including vitamins, proteins, and minerals and the stems are also used as fodder for livestock, especially in the dry spell following the main cropping season. As a legume, common bean plants also contribute to soil fertility enhancement through atmospheric nitrogen fixation. Most common bean production in the developing world occurs under conditions where the risk of drought is high.

The present investigation revealed the presence of genetic variability among varieties with respect to different traits. The presence of significant difference among common bean varieties for the studied traits ensured the presence of large genetic variation to be improved through selection. The presence of considerable variation in the genetic materials implied that the possibility to improve the genotypes with simple selection for the studied traits. Plant breeding is primarily depending on presence of substantial genetic variation to address the maximum genetic yield potential of the crops and exploitation of these variations through effective selection for further improvement. This significant genetic variation among genotypes suggested that the varieties were genetically diverse and it could be a good opportunity for breeders to select genotypes for trait of interest for variety development.

Hence, the obtained results encourage the availabilities of substantial genetic variation among varieties for the major studied traits. The potential common bean varieties identified based on the superior mean yield performance and other related traits. Analysis of variance showed highly significant varietal differences days to $50 \%$ flowering and Days to $90 \%$ maturity at $1 \%$ probability level and very highly significant difference observed for grain yield and ground cover at $0.1 \%$ probability level. The combined means result indicated that the SER-125 (2620 kgha-1) and SER-19 (2612 kgha-1) common bean varieties had the highest yield respectively. The earliness trait (days to flowering and days to physiological maturity) enables them to flower and mature early, therefore escaping from moisture stress, the most important drought factors that results in reduced yield. Most of the varieties showed adaptation to drought stress by reducing their days to physiological maturity, thereby minimizing the effect of drought. As compared to the others, SER-125 and SER-19 common bean varieties were recommended as promising varieties to the farmers of Mieso area and other districts having the same agro-ecologies based on their optimal yield performance for further adoption.

\section{REFERENCES}

[1] Alemu, H., 2017. Review paper on breeding common bean (Phaseolus vulgaris L.) genotypes for acidic soil tolerance. International Journal of Advanced research and publications, 1(3), pp.39-46.

[2] Amsalu, B., Negash, K., Shiferaw, T., Tumssa, K., Tsegaye, D., Claude, R.J. and Mukankusi, C.M., 2018. Progress of common bean breeding and genetics research in Ethiopia. Ethiopian Journal of Crop Science.

[3] Asfaw, A. and Blair, M.W., 2014. Quantification of drought tolerance in Ethiopian common bean varieties. Agricultural Sciences, 2014.

[4] Asfaw, A., Almekinders, C.J., Blair, M.W. and Struik, P.C., 2012. Participatory approach in common bean (Phaseolus vulgaris L.) breeding for drought tolerance for southern Ethiopia. Plant breeding, 131(1), pp.125-134.

[5] Assefa, T., Wu, J., Beebe, S.E., Rao, I.M., Marcomin, D. and Claude, R.J., 2015. Improving adaptation to drought stress in small red common bean: phenotypic differences and predicted genotypic effects on grain yield, yield components and harvest index. Euphytica, 203(3), pp.477-489.

[6] Beebe, S.E., Rao, I.M., Cajiao, C. and Grajales, M., 2013. Selection for drought resistance in common bean also improves yield in phosphorus limited and favorable environments. Crop Science, 48(2), pp.582-592.

[7] Bitocchi, E., Bellucci, E., Giardini, A., Rau, D., Rodriguez, M., Biagetti, E., Santilocchi, R., Spagnoletti Zeuli, P., Gioia, T., Logozzo, G. and Attene, G., 2013. Molecular analysis of the parallel domestication of the common bean (P Phaseolus vulgaris) in Mesoamerica and the Andes. New Phytologist, 197(1), pp.300-313.

[8] Ceccarelli, S., Grando, S. and Baum, M., 2007. Participatory plant breeding in water-limited environments. Experimental Agriculture, 43(4), pp.411-435.

[9] CSA, 2019. Ethiopia Agricultural Sample Survey 2019/2020. Report on Land Utilization (Private Peasant Holdings, Meher Season). Central Statistical Agency (CSA), Federal Democratic Republic of Ethiopia, Addis Ababa, Ethiopia. 
Evaluation of Improved Common Bean (Phaseolus vulgaris L.) Varieties for Yield and Yield Components at West Hararghe, Eastern Ethiopia

[10] Gereziher, T., Seid, E. and Bisrat, G., 2017. Performance evaluation of common bean (Phaseolus vulgaris L.) varieties in Raya Valley, Northern Ethiopia. African Journal of Plant Science, 11(1), pp.1-5.

[11] Gomez AA, Gomez KA. (1984). Statistical procedures for agricultural research, 2nd edition. John wiley and Sons Inc., New York.

[12] Høgh-Jensen H, Myaka FM, Kamalongo D, Ngwira A. The bean - naturally bridging agriculture and human well-being. In: Muzzalupo I, editor. Food Industry: InTech, Rijeka, Croatia, chapter 2; 2013. p. 23-38. 3.

[13] Katungi, E., Farrow, A., Chianu, J., Sperling, L. and Beebe, S., 2009. Common bean in Eastern and Southern Africa: a situation and outlook analysis. International Centre for Tropical Agriculture, 61, pp.1-44.

[14] Krupa, U., 2008. Main nutritional and antinutritional compounds of bean seeds-a review. Polish journal of food and nutrition sciences, 58(2).

[15] Legesse, H., Nigussie-Dechassa, R., Gebeyehu, S., Bultosa, G. and Mekbib, F., 2013. Response to soil acidity of common bean genotypes (Phaseolus vulgaris L.) under field conditions at Nedjo, Western Ethiopia. Science, Technology and Arts Research Journal, 2(3), pp.03-15.

[16] Lemma, W., 2008. Physicochemical studies of soils of Miesso areas, Eastern Hararghe, Oromia region (Doctoral dissertation, MSc Thesis presented to the School of Graduate Studies of Haramaya University. Haramaya, Ethiopia).

[17] Livestock, C.S.A., 2017. Livestock characteristics, agricultural sample survey. Addis Ababa, Ethiopia. Statistical Bulletin, 2(583), pp.9-13.

[18] Mamidi, S., Rossi, M., Moghaddam, S.M., Annam, D., Lee, R., Papa, R. and McClean, P.E., 2013. Demographic factors shaped diversity in the two gene pools of wild common bean Phaseolus vulgaris L. Heredity, 110(3), pp.267-276.

[19] McConnell M, Mamidi S, Lee R, Chikara S, Rossi M, Papa R and McClean P., 2013: Syntenic relationships among legumes revealed using a gene-based genetic linkage map of common bean (Phaseolus vulgaris L.). Theor Appl Genet, 121:1103-1116.

[20] Mercati, F., Leone, M., Lupini, A., Sorgona, A., Bacchi, M., Abenavoli, M.R. and Sunseri, F., 2013. Genetic diversity and population structure of a common bean (Phaseolus vulgaris L.) collection from Calabria (Italy). Genetic resources and crop evolution, 60(3), pp.839-852.

[21] Merga, J.T., 2020. Evaluation of common bean varieties (Phaseolus vulgaris L.) to different row-spacing in Jimma, South Western Ethiopia. Heliyon, 6(8), p.e04822.

[22] Miklas, P.N., Kelly, J.D., Beebe, S.E. and Blair, M.W., 2006. Common bean breeding for resistance against biotic and abiotic stresses: from classical to MAS breeding. Euphytica, 147(1), pp.105-131.

[23] Mitiku, M. and Mesera, T., 2017. Performance Evaluation of Common Bean (Phaseolus Vulgaris (L.)) Varieties at Benatsemay woreda of South Omo Zone, SNNPR, Ethiopia. Int J Agric Biosci, 6(6), pp.277-280.

[24] Petry, N., Boy, E., Wirth, J.P. and Hurrell, R.F., 2015. The potential of the common bean (Phaseolus vulgaris) as a vehicle for iron bio fortification. Nutrients, 7(2), pp.1144-1173.

[25] Porch, T.G., Beaver, J.S., Debouck, D.G., Jackson, S.A., Kelly, J.D. and Dempewolf, H., 2013. Use of wild relatives and closely related species to adapt common bean to climate change. Agronomy, 3(2), pp.433-461.

[26] SAS Institute Inc (2018). SAS /STAT users guide. Version 9.4, 4th edition. Cat, NC.

[27] Schmutz, J., McClean, P.E., Mamidi, S., Wu, G.A., Cannon, S.B., Grimwood, J., Jenkins, J., Shu, S., Song, Q., Chavarro, C. and Torres-Torres, M., 2014. A reference genome for common bean and genome-wide analysis of dual domestications. Nature genetics, 46(7), pp.707-713.

[28] Shabib, J.M., Shehata, A.I., Alndash, A.A. and Al-rumaih, M., 2013. Assessment the genetic diversity of common bean Phaseolus vulgaris collection by microsatellite SSR markers. African Journal of Agricultural Research, 8(40), pp.5032-5046.

[29] Terán, H. and Singh, S.P., 2002. Comparison of sources and lines selected for drought resistance in common bean. Crop Science, 42(1), pp.64-70.

[30] Tumsa, K., Buruchara, R. and Beebe, S.E., 2014. Common bean strategies and seed roadmaps for Ethiopia. Grain Legumes Strategies and Seed Roadmaps for Selected Countries in Sub Saharan Africa and South Asia, TL-II Project Report, ICRISAT, India, pp.3-11. 
Evaluation of Improved Common Bean (Phaseolus vulgaris L.) Varieties for Yield and Yield Components at West Hararghe, Eastern Ethiopia

[31] Wondatir, Z. and Mekasha, Y., 2014. Feed resources availability and livestock production in the central rift valley of Ethiopia. International Journal of livestock production, 5(2), pp.30-35.

[32] Yirga, C., Rashid, S., Behute, B. and Lemma, S., 2019. Pulses value chain potential in Ethiopia: Constraints and opportunities for enhancing exports. Gates Open Res, 3(276), p.276.

Citation: Temesgen Begna and Zewdu Asrat, (2021). "Evaluation of Improved Common Bean (Phaseolus vulgaris L.) Varieties for Yield and Yield Components at West Hararghe, Eastern Ethiopia”, International Journal of Research Studies in Agricultural Sciences (IJRSAS), 7(9), pp. 5-12 DOI: http://dx.doi.org/ 10.20431/2454-6224.0709002

Copyright: (C) 2021 Authors. This is an open-access article distributed under the terms of the Creative Commons Attribution License, which permits unrestricted use, distribution, and reproduction in any medium, provided the original author and source are credited. 